\title{
Case Based Reasoning Diagnosis Gangguan Pencernaan pada Anak Menggunakan Metode Similarity Cosine Coefficient
}

\author{
Shara Shorea Pratiwi ${ }^{\# 1}$, Tursina ${ }^{\# 2}$, Helen Sasty Pratiwi ${ }^{\# 3}$ \\ \#Program Studi Informatika, Fakultas Teknik, Universitas Tanjungpura \\ Jl. Prof. Dr. Hadari Nawawi, Pontianak 78124 \\ ${ }^{1}$ shara.shorealgmail.com \\ ${ }^{2}$ tursinalinfromatika.untan.ac.id \\ ${ }^{3}$ helensastypratiwi@gmail.com
}

\begin{abstract}
Abstrak- Gangguan pencernaan pada umumnya terjadi karena kebiasaan anak yang suka memakan makanan yang kurang bersih atau sembarang dan memasukkan benda asing kedalam mulutnya. Gangguan pencernaan pada anak kadang tampak ringan seperti tidak ada gangguan bahkan orang tua seringkali menganggapnya sebagai sesuatu yang normal. Orang tua yang mempunyai peran utama dalam memperhatikan kesehatan anak terkadang kurang mengetahui jenis gejala maupun gangguan pencernaan yang diderita oleh anaknya. Sehingga diperlukan sistem yang dapat menghasilkan pengetahuan dan pengalaman seperti seorang dokter atau tenaga medis dalam mendiagnosis gangguan pencernaan tersebut. Sistem dengan implementasi case based reasoning metode cosine coefficient ini tentu akan mempermudah membantu masyarakat dalam mendiagnosis awal terhadap gangguan pencernaan pada anak serta solusinya. Proses penalaran berbasis kasus melalui 4 tahap yaitu retrieve (penelusuran kasus) pada tahapan retrieve menggunakan metode cosine coefficient untuk mencari nilai kemiripan, reuse (menggunakan solusi yang sama), revise (merevisi solusi yg diusulkan), dan retain (penyimpanan kasus). Hasil keluaran dari sistem ini adalah jenis gangguan pencernaan pada anak beserta solusinya. Pengujian sistem dilakukan dengan dua cara, yaitu pengujian tahapan case based reasoning dan kesesuaian hasil diagnosis pakar dan hasil diagnosis sistem. Berdasarkan hasil pengujian yang di lakukan sistem dapat bekerja dengan baik dan sistem dapat mendiagnosis gangguan pencernaan pada anak.
\end{abstract}

Kata kunci - anak, gangguan pencernaan, case based reasoning, cosine coefficient, web

\section{Pendahuluan}

Pada tahun 2004 insidensi gangguan saluran pencernaan terutama diare memiliki angka kejadian yang tinggi dibandingkan penyakit lainnya yaitu 4620,4 juta di dunia [1]. Diare merupakan penyakit nomor 1 dalam 10 besar penyakit terbesar di Indonesia [2]. Di Indonesia, diare merupakan salah satu penyebab kematian kedua terbesar pada balita. Di Indonesia sekitar 162 ribu balita meninggal setiap tahun atau sekitar 460 balita setiap harinya [3].

Anak usia Sekolah Dasar (SD) adalah anak yang berusia 6 sampai 12 tahun. Masa ini merupakan akhir masa kanakkanak (late chilhood) yang berlangsung dari usia 6 tahun sampai tibanya anak menjadi matang secara seksual, yaitu 13 tahun bagi perempuan dan 14 tahun bagi laki-laki [4]. Karakteristik anak sekolah secara kebiasaan anak sering tidak sarapan dengan mengganti makanan yang mengandung kalori atau zat gizi yang rendah [5], anak-anak banyak menonton televisi dan menirunya. Kondisi ini mencerminkan kebiasaan makan jajan yang buruk yang berpengaruh terhadap status gizi [6].

Seringkali anak mengeluhkan rasa sakit pada bagian perut, diare atau susah buang air besar yang merupakan salah satu tanda awal terjadinya gangguan pencernaan. Gangguan pencernaan pada umumnya terjadi karena kebiasaan anak yang suka memakan makanan yang kurang bersih atau sembarang dan memasukkan benda asing kedalam mulutnya. Gangguan pencernaan pada anak kadang tampak ringan seperti tidak ada gangguan bahkan orang tua seringkali menganggapnya sebagai sesuatu yang normal. Orang tua yang mempunyai peran utama dalam memperhatikan kesehatan anak terkadang kurang mengetahui jenis gejala maupun gangguan pencernaan yang diderita oleh anaknya. Ketika anak mengalami gangguan pencernaan orang tua lebih mempercayakan kepada dokter atau pakar untuk membantu menangani serta memberikan solusi sehingga tidak jarang orang tua mendatangi puskesmas atau rumah sakit sehingga para orang tua akan mengeluarkan biaya yang tidak sedikit hanya untuk berkonsultasi dengan dokter atau pakar, padahal gejala gangguan pencernaan tersebut bisa diatasi sendiri atau harus ditangani secara medis. 
Berdasarkan permasalahan yang dipaparkan, maka diperlukan suatu sistem yang dapat menghasilkan pengetahuan dan pengalaman seperti seorang dokter atau tenaga medis dalam mendiagnosis gangguan pencernaan tersebut. Sehingga masyarakat khususnya orang tua bisa melakukan pencegahan agar penyakitnya tidak berkembang dan semakin parah. Sistem yang dibangun berdasarkan dari kasus-kasus gangguan pencernaan yang pernah ditangani oleh dokter atau tenaga medis. Data kasus tersebut berupa gejala gangguan pencernaan yang dialami oleh penderita.

Untuk itu diperlukan metode pencarian kasus dengan kemampuan yang dapat mendeskripsikan masalah, mencari permasalahan/informasi yang mirip didalam bank kasus, menggunakan pertanyaan pertanyaan agar mendapatkan fokus permasalahan yang paling mirip, dapat memberikan solusi berdasarkan permasalahan yang paling mirip serta dapat beradaptasi terhadap kasus baru untuk menemukan solusi. Kemampuan yang seperti disebutkan tersebut merupakan ciriciri dari case based reasoning (CBR).

Untuk mendapatkan solusi maka kemiripan antara kasus baru dan kasus lama harus dihitung dengan menggunakan metode similaritas. Salah satu metode untuk menghitung similaritas ialah metode cosine coefficient. Metode cosine coefficient adalah metode untuk menghitung similaritas dua objek (items) yang bersifat biner dengan membandingkan fitur yang match dengan banyaknya gejala atau fitur pada kasus yang diuji dan fitur pada kasus baru yang bernilai 1. [7]

Sistem yang akan dibangun berbasis web agar dapat diakses dengan mudah oleh siapa saja, perangkat dengan sistem operasi apa saja dan tanpa perlu melakukan penginstalan. Keberadaan sistem ini diharapkan dapat membantu masyarakat dalam mendiagnosis awal terhadap gangguan pencernaan pada anak dan memberikan saran serta solusi terhadap gangguan pencernaan tersebut.

Hendra dkk menggunakan metode Tversky dalam penentuan harga rumah. Penelitian ini berdasarkan kriteria yang di-input-kan pada sistem pembeli dapat memeriksa harga umum dari rumah sehingga harga yang ditawarkan tidak terlalu tinggi dan terlalu rendah. Penggunaan sistem diharapkan mampu mengurangi ketidaksesuaian harga yang ditawarkan pemilik rumah terhadap pencari rumah dengan cara membandingkan harga penawaran terhadap harga umum dalam sistem yang tidak memiliki selisih harga yang banyak. Hasil akhir dari penelitian ini adalah sebuah aplikasi implementasi dari Case Base Reasoning yang dapat digunakan untuk menentukan harga rumah berdasarkan kasuskasus penjualan rumah sebelumnya. Sistem akan memproses data input dari user sehingga dapat menghasilkan output harga rumah.[8]

Mohamad dkk menggunakan knowledge base pada aplikasi data orang hilang di polres tasikmalaya kota yang metode penelusuran yang digunakan pada penelitian ini adalah penelusuran runut maju (forward chaining). Sistem yang dapat melakukan identifikasi data orang hilang berdasarkan pengetahuan (knowledge). Hasil akhir dari penelitian ini adalah sebuah aplikasi yang berjalan sesuai dengan harapan.[9]

\section{URAIAN PENELITIAN}

\section{A. Anatomi dan Fisiologi Sistem Saluran Pencernaan}

Sistem pencernaan berurusan dengan penerimaan makanan dan mempersiapkannya untuk diasimilasi oleh tubuh. Saluran pencernaan terdiri atas bagian-bagian berikut : mulut, faring, esofagus, ventrikulus, usus halus dan usus besar, tekak, kerongkongan dan lambung. [10]

Fungsi sistem pencernaan. Fungsi utama sistem ini adalah untuk menyediakan makanan, air dan elektrolit bagi tubuh dari nutrien yang dicerna sehingga siap diabsorbsi. Pencernaan dapat berlangsung secara mekanik dan kimia. [11]

Proses-proses dalam kegiatan pencernaan adalah sebagai berikut :

1. Ingesti : masuknya makanan kedalam mulut

2. Pemotongan dan penggilingan makanan dilakukan secara mekanik oleh gigi, makanan kemudian bercampur dengan saliva sebelum ditelan.

3. Peristaltis : gelombang kontraksi otot polos involunte yang menggerakkan makanan tertelan melalui saluran pencernaan.

4. Digesti : hidrolisis kimia (penguraian) molekul besar menjadi molekul kecil sehingga absorbsi dapat berlangsung.

5. Absorbsi : pergerakan produk akhir pencernaan dari lumen selauran pencernaan ke dalam sirkulasi darah dan limfatik sehingga digunakan oleh sel tubuh.

6. Egesti (defekasi) : proses eliminasi zat-zat sisa yang tidak tercerna, juga bakteri dalam bentuk feses dari saluran pencernaan.

Diare merupakan kondisi dimana terjadi perubahan dalam kepadatan dan karakter tinja, atau tinja cair dikeluarkan tiga kali atau lebih perhari [12]. Diare merupakan salah satu gejala dari penyakit pada sistem gastrointestinal atau penyakit lain diluar saluran pencernaan [13]. Jadi diare adalah buang air besar yang frekuensinya lebih dari 3 kali sehari dengan konsistensi tinja yang encer [14]. Di negara yang sedang berkembang, insiden yang tinggi dari penyakit diare merupakan kombinasi dari sumber air yang tercemar, kekurangan protein dan kalori yang menyebabkan turunnya daya tahan tubuh [15].

\section{B. Case Based Reasoning (CBR)}

Case based reasoning (CBR) merupakan salah satu penalaran yang digunakan dalam pemecahan masalah dengan mencari solusi dari suatu kasus yang baru, sistem akan melakukan pencarian terhadap solusi dari kasus lama yang memiliki permasalahan yang sama dan sudah pernah terjadi sebelumnya. 
Terdapat dua prinsip dasar pada metode CBR, prinsip pertama adalah setiap permasalahan yang sama akan memiliki solusi yang sama pula. Oleh karena itu, solusi dari permasalahan yang sudah pernah terjadi dapat digunakan kembali untuk memecahkan masalah baru dengan permasalahan yang sama dengan masalah yang lama. Prinsip kedua adalah setiap permasalahan dapat terjadi berulang kali. Oleh karena itu, terdapat kemungkinan bahwa masalah yang akan muncul di masa yang akan datang memiliki kesamaan dengan masalah yang pernah terjadi sebelumnya [16].

Case-Based Reasoning adalah suatu pendekatan untuk menyelesaikan suatu permasalahan (problem solving) berdasarkan solusi dari permasalahan sebelumnya. Case-based Reasoning ini merupakan suatu paradigma pemecahan masalah yang banyak mendapat pengakuan yang pada dasarnya berbeda dari pendekatan utama AI lainnya. Suatu masalah baru dipecahkan dengan menemukan kasus yang serupa di masa lampau, dan menggunakannya kembali pada situasi masalah yang baru. Perbedaan lain dari CBR yang tidak kalah penting adalah CBR juga merupakan suatu pendekatan ke arah incremental yaitu pembelajaran yang terus-menerus.[17]

Alur proses Case Base Reasoning (CBR) dapat dilihat Pada Gambar 1. [18]

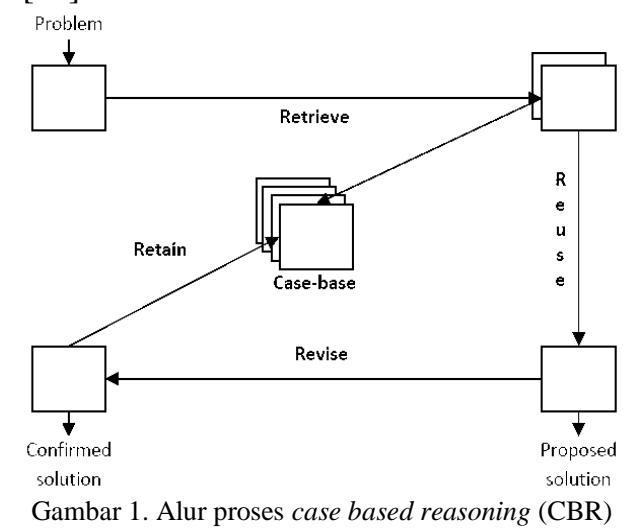

Keterangan :

1. Retrieve, mendapatkan kasus-kasus yang mirip

2. Reuse, Menggunakan kembali kasus-kasus yang mirip dan dicoba untuk menyelesaikan suatu masalah sekarang

3. Revise, merubah dan mengadopsi solusi yang ditawarkan jika perlu

4. Retain, memakai solusi baru sebagai bagian dari kasus baru kemudian kasus baru di-update kedalam basis kasus

\section{Metode Cosine Coefficient}

Cosine Coefficient adalah satu cara untuk menghitung similaritas dua objek (items) yang bersifat biner. Perhitungan similaritas digunakan untuk menghasilkan nilai apakah ada kemiripan atau tidak antara kasus baru dengan kasus yang telah ada di basis kasus. Formula yang digunakan Cosine Coefficient (Cos SM) untuk menghitung similarity antara dua objek adalah dengan rumus sebagai berikut [7]. Perhitungan untuk mencari nilai kemiripan menggunakan cosine coefficient ditunjukkan pada persamaan 1 .

$$
\operatorname{Cos} \mathrm{SM}_{i}, s_{\mathrm{j}}=\frac{\sum_{j=1}^{M}\left(\mathrm{~W}_{s i}, t j \cdot \mathrm{W}_{s j, t j)}\right.}{\sqrt{\sum_{j=1}^{M}\left(\mathrm{~W}_{s i}, t j\right)^{2} \sum_{j=1}^{M}\left(\mathrm{~W}_{s j}, t j\right)^{2}}}
$$

\section{Unified Modelling Languange (UML)}

UML merupakan bahasa visual untuk pemodelan dan komunikasi mengenai sistem dengan menggunakan diagram dan teks-teks pendukung. UML muncul karena adanya kebutuhan pemodelan visual untuk menspesifikasikan, menggambarkan, membangun dan dokumentasi dari sistem perangkat lunak [19].

\section{Use Case Diagram}

Use case diagram mendeskripsikan sebuah interaksi antara satu atau lebih aktor dengan sistem informasi yang akan dibuat. Dengan kata lain, use case diagram digunakan untuk mengetahui fungsi-fungsi apa saja yang terdapat di dalam sistem dan siapa saja yang berhak mengakses fungsi tersebut [19].

\section{Activity Diagram}

Diagram aktifitas menggambarkan aliran kerja atau aktifitas dari sebuah sistem atau proses bisnis, yang perlu diperhatikan disini adalah bahwa diagram aktifitas menggambarkan aktifitas sistem bukan apa yang dilakukan aktor, jadi aktifitas yang dapat dilakukan oleh sistem [19].

3. Sequence Diagram

Sequence diagram menggambarkan interaksi antara sejumlah objek dalam urutan waktu. Kegunaanya untuk menunjukkan rangkaian pesan yang dikirim antara objek juga interaksi antar objek yang terjadi pada titik tertentu dalam eksekusi sistem. Sequence diagram menunjukkan interaksi dengan menampilkan setiap partisipan dengan garis alir secara vertikal dengan pengurutan pesan dari atas ke bawah [20].

4. Class Diagram

Class diagram menggambarkan struktur sistem dari segi pendefinisian kelas-kelas yang akan dibuat untuk membangun sistem. Kelas memiliki apa yang disebut atribut dan metode atau operasi. Atribut merupakan variabel-variabel yang dimiliki oleh suatu kelas. Metode atau operasi adalah fungsi-fungsi yang dimiliki oleh suatu kelas [19].

\section{PERANCANGAN SISTEM}

\section{A. Perancangan Arsitektur Sistem}

Adapun arsitektur sistem yang akan dibangun dapat dilihat pada Gambar 2 berikut 


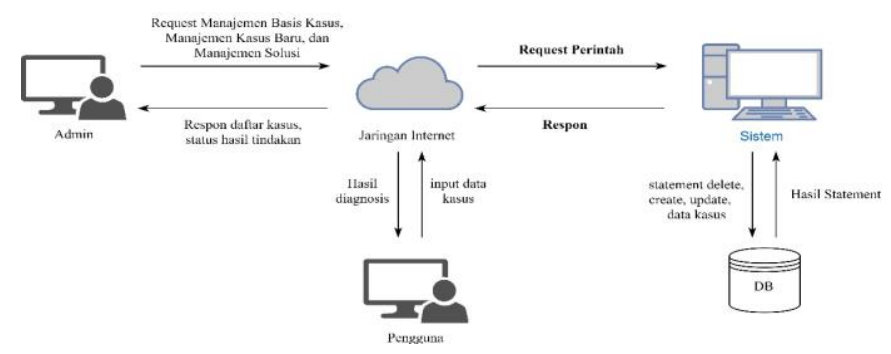

Gambar 2. Perancangan arsitektur sistem

\section{B. Use Case Diagram}

Berikut adalah diagram use case dari sistem diagnosis gangguan pencernaan pada anak:

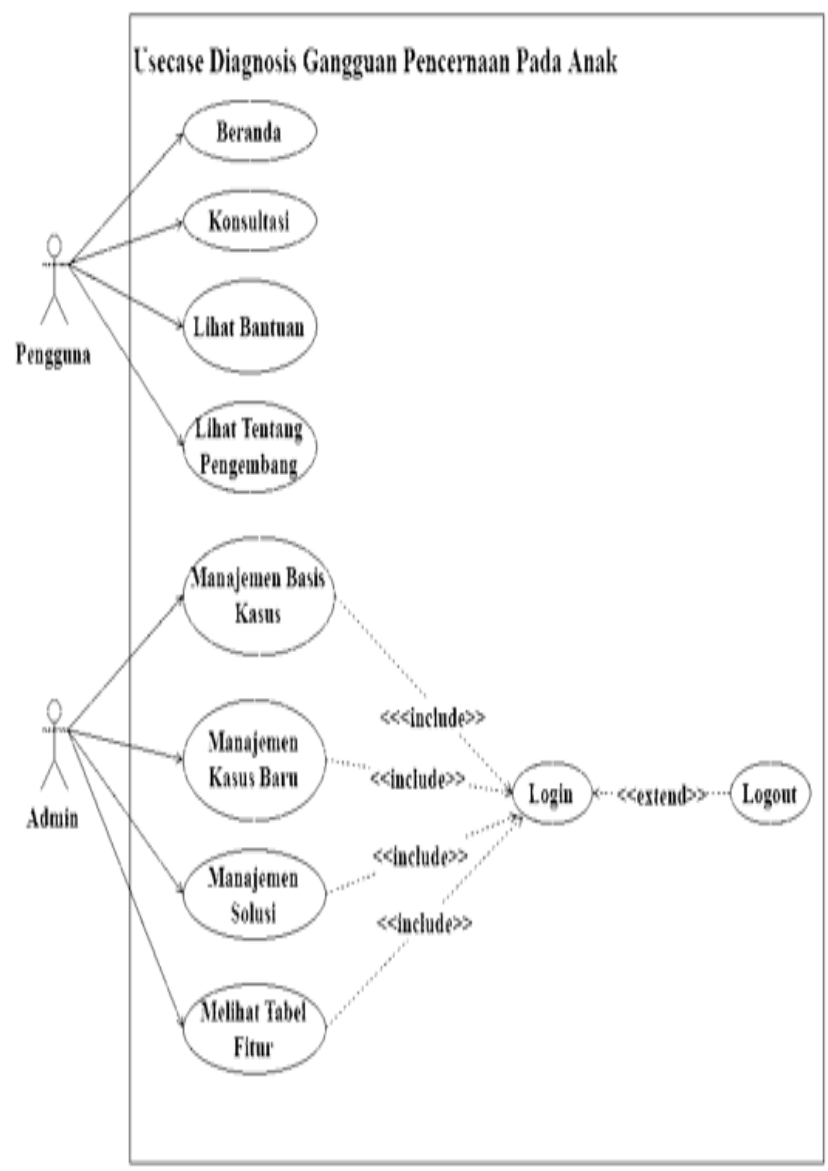

Gambar 3. Use case diagram

\section{Hasil Perancangan Sistem}

Sistem yang dibangun merupakan sistem diagnosis gangguan pencernaan pada anak dengan menggunakan metode similaritas cosine coefficient. Berikut tampilan hasil perancangan aplikasi.

Gambar 4 merupakan halaman utama pengunjung saat pertama kali menjalankan sistem.

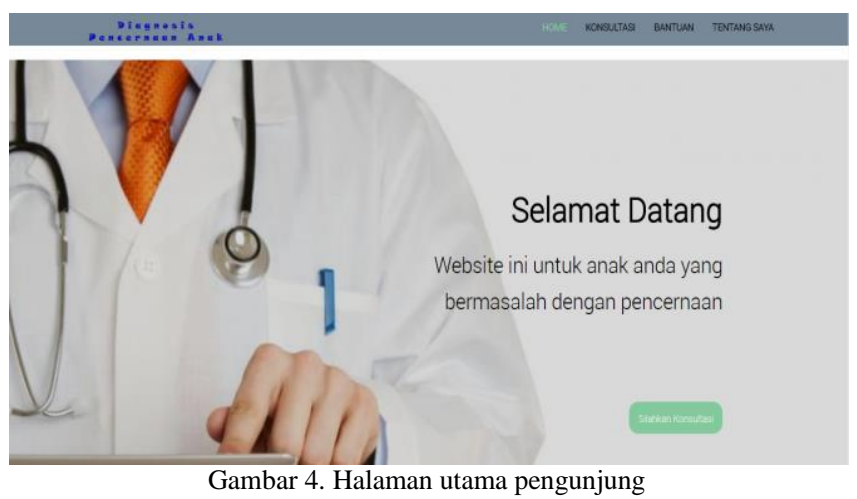

Gambar 5 merupakan halaman ketika admin akan melakukan login.

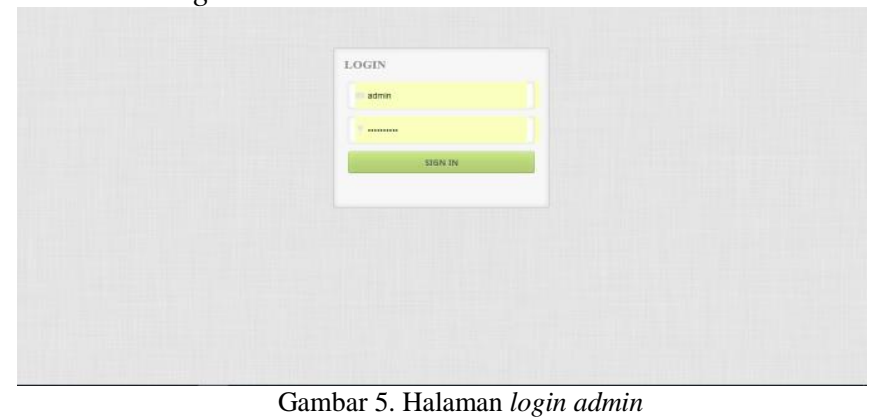

D. Hasil Pengujian

1. Pengujian Tahapan Case Based Reasoning

a. Tahapan Retrieve adalah untuk menelusuri dan mendapatkan kasus-kasus yang mirip dibandingkan dengan kumpulan kasus-kasus dimasa lalu (basis kasus).

Tahapan retrieve yaitu :

Melakukan inputaann data dan melakukan diagnosis gangguan pencernaan pada anak. Gambar 6 merupakan proses input data gejala gangguan pencernaan.

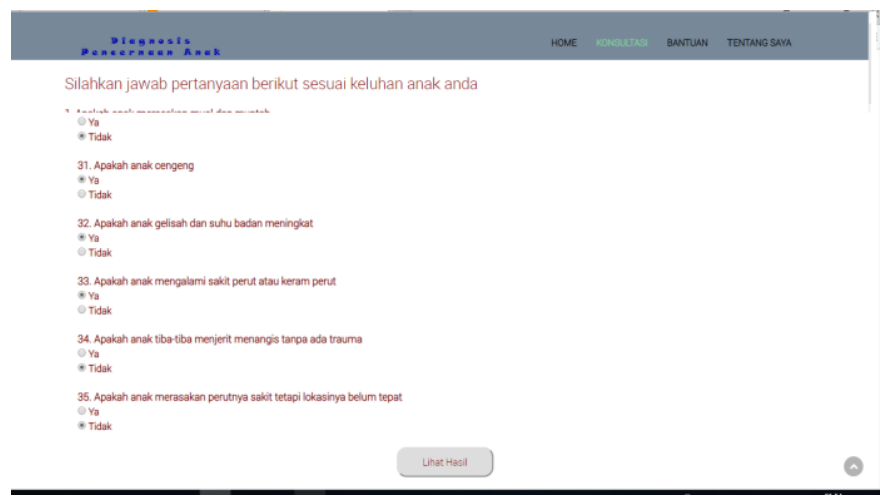

Gambar 6. Menu input data gejala gangguan

Mencari tingkat kemiripan dengan metode cosine coefficient antara kasus baru dengan kasus-kasus dalam basis pengetahuan pada Gambar 7 berikut 


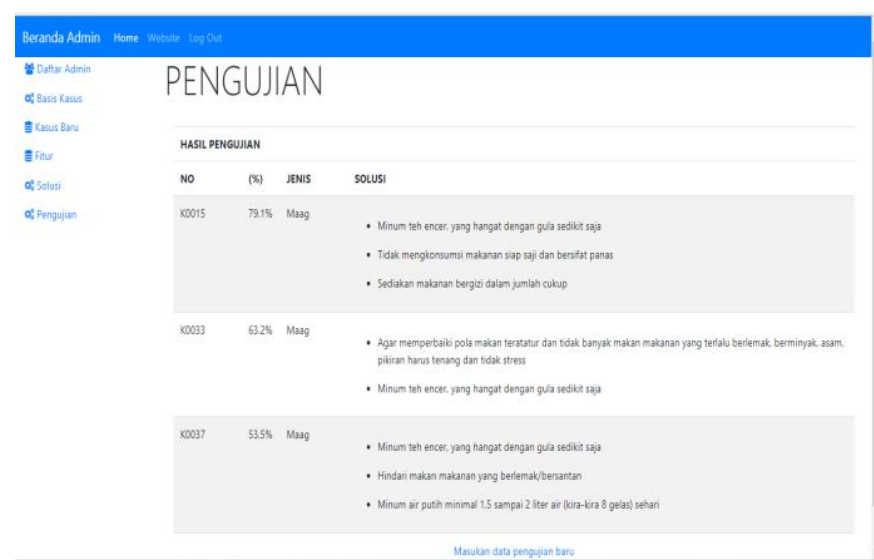

Gambar 7. Halaman hasil diagnosis dengan tingkat kemiripan kasus baru dengan kasus lama dengan nilai tertinggi

b. Tahapan Reuse adalah menggunakan kembali kasus-kasus yag ada dan dicoba untuk menyelesaikan suatu masalah sekarang yang ditunjukkan pada Gambar 8 berikut:

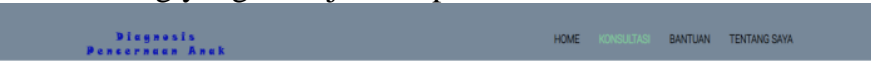

Hasil Konsultasi

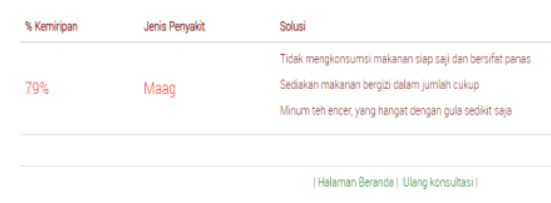

pencernacis anot

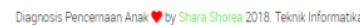

\section{(웅}

Gambar 8. Kasus lama yang digunakan sebagai solusi

c. Tahapan Revise merupakan tahapan merubah dan mengadopsi solusi yang ditawarkan jika perlu. Tahapan Revise di tunjukkam pada Gambar 9 berikut:

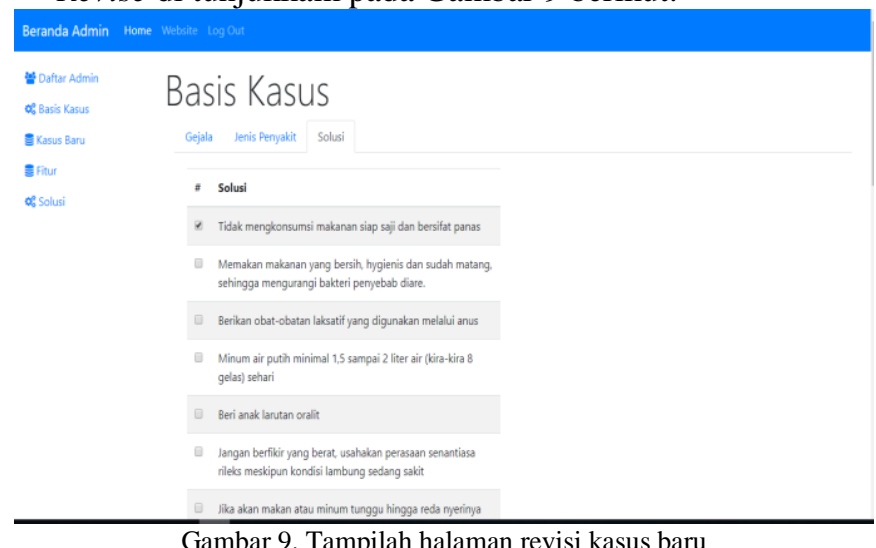

d. Tahapan Retain terjadi proses penggabungan dari solusi kasus yang baru yang benar ke basis kasus yang telah ada. Tahapan retain di tunjukkan pada Gambar 10 berikut:

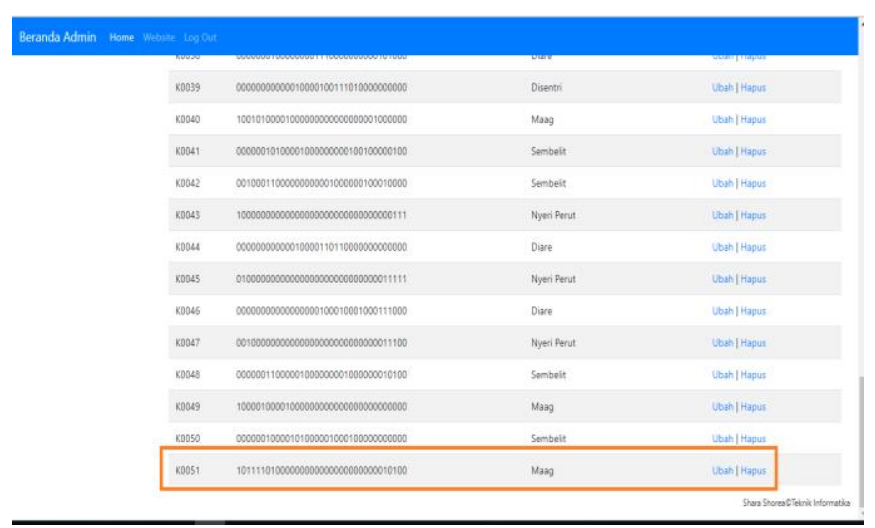

Gambar 10. Tampilan tahapan retain

2. Pengujian Membandingkan Hasil Diagnosis Pakar dengan Hasil Diagnosis Sistem

Pada pengujian ini dilakukan dengan cara membandingkan hasil diagnosis kasus baru yang dilakukan oleh pakar (dokter) dengan hasil diagnosis oleh sistem. Jumlah kasus uji sebanyak 25 kasus. Hasil pengujian dapat dilihat pada Tabel 1.

TABEL 1

PENGUJIAN MEMBANDINGKAN HASL DIAGNOSIS PAKAR DENGAN HASIL DIAGNOSIS SISTEM

\begin{tabular}{|c|l|l|l|l|}
\hline \multirow{2}{*}{$\begin{array}{c}\text { No } \\
\text { Kasus. }\end{array}$} & \multirow{2}{*}{ Hasil Pakar } & \multicolumn{2}{|c|}{ Hasil Sistem } & $\begin{array}{c}\text { Kesesuaian } \\
\text { Hasil }\end{array}$ \\
\cline { 3 - 5 } & & Diagnosis & Sim & \\
\hline 1 & Maag & Maag & 0,79 & Sesuai \\
\hline 2 & Maag & Maag & 0,91 & Sesuai \\
\hline 3 & Sembelit & Sembelit & 0,79 & Sesuai \\
\hline 4 & Sembelit & Sembelit & 0,77 & Sesuai \\
\hline 5 & Maag & Maag & 0,73 & Sesuai \\
\hline 6 & Maag & Maag & 1 & Sesuai \\
\hline 7 & Disentri & Sembelit & 0,54 & Tidak Sesuai \\
\hline 8 & Disentri & Disentri & 0,84 & Sesuai \\
\hline 9 & Disentri & Disentri & 1 & Sesuai \\
\hline 10 & Sembelit & Sembelit & 0,67 & Sesuai \\
\hline 11 & Sembelit & Sembelit & 0,81 & Sesuai \\
\hline 12 & Sembelit & Sembelit & 0,83 & Sesuai \\
\hline 13 & Diare & Diare & 0,81 & Sesuai \\
\hline 14 & Sembelit & Sembelit & 0,91 & Sesuai \\
\hline 15 & Diare & Diare & 0,75 & Sesuai \\
\hline 16 & Maag & Maag & 0,79 & Sesuai \\
\hline 17 & Disentri & Disentri & 0,81 & Sesuai \\
\hline 18 & Sembelit & Sembelit & 0,83 & Sesuai \\
\hline 19 & Diare & Diare & 0,79 & Sesuai \\
\hline 20 & Diare & Diare & 0,66 & Sesuai \\
\hline 20 & Diare & Diare & 0,66 & Sesuai \\
\hline 21 & Radang Usus & Radang Usus & 0,84 & Sesuai \\
\hline 22 & Buntu & Buntu & & \\
\hline 23 & Disentri & Nyeri Perut & 0,81 & Sesuai \\
\hline 24 & Diare & Diare & 0,50 & Tidak Sesuai \\
\hline 25 & Diare & Nyeri perut & 0,68 & Tidak Sesuai \\
\hline & & & & \\
\hline
\end{tabular}

\section{E. Analisis Hasil Pengujian}

Analisis hasil pengujian aplikasi diagnosis gangguan pencernaan dapat disimpulkan sebagai berikut: 
1. Hasil pengujian tahapan case based reasoning menunjukkan bahwa sistem ini dapat melakukan tahapan retrieve (mendapatkan kasus-kasus yang mirip), reuse (menggunakan kembali kasus-kasus yang ada dan dicoba unutuk menyelesaikan suatu masalah sekarang), revise (merubah dan mengadopsi solusi yang ditawarkan jika perlu) dan retain (memakai solusi baru sebagai bagian dari kasus baru, kemudian kasus baru di-update ke dalam basis kasus).

2. Hasil pengujian dengan perhitungan metode cosine coefficient pada Tabel 4.3 dengan jumlah basis kasus sebanyak 50 kasus, dari total 25 sampel uji hanya 4 sampel yang memberikan hasil yang tidak sesuai/ dan 21 sampel lainnya memberikan hasil yang sesuai. Sehingga jika dihitung persentasenya, hasil yang sesuai yaitu $(21 / 25) \mathrm{x}$ $100 \%=84 \%$ dan yang tidak sesuai sebesar $(4 / 25) \times 100 \%$ $=16 \%$.

Berdasarkan hasil pengujian dengan perhitungan metode cosine coefficient yang telah dilakukan, diketahui bahwa perbedaan dapat terjadi antara hasil diagnosis oleh pakar dengan diagnosis sistem. Perbedaan hasil diagnosis ini dapat disebabkan karena jumlah kasus pada basis kasus adalah sebanyak 50 kasus, jumlah basis kasus ini masih tergolong sedikit. Sedangkan pada case based reasoning semakin banyak pengalaman, sistem akan menjadi semakin pintar sehingga dapat memecahkan masalah dengan mudah dan memberikan solusi lebih akurat dengan nilai similaritas lebih tinggi.

\section{KESIMPULAN}

Berdasarkan hasil analisis dan pengujian terhadap program aplikasi diagnosis gangguan pencernaan pada anak, dapat disimpulkan bahwa:

1. Sistem yang dihasilkan dapat memberikan solusi berdasarkan kasus gangguan pencernaan pada anak sebelumnya dengan tingkat keberhasilan $84 \%$ dan tingkat kegagalan $16 \%$.

2. Dari hasil pengujian, sistem dapat bekerja dengan baik dan dapat mendiagnosis gangguan pencernaan dengan melakukan tahapan Case Based Reasoning yaitu tahapan retrieve (mendapatkan kasus-kasus gangguan pencernaan yang mirip) pada tahapan retrieve untuk mencari nilai kemiripan dengan menggunakan metode cosine coefficient, reuse (menggunakan kembali kasus-kasus gangguan pencernaan yang ada dan dicoba unutuk menyelesaikan suatu masalah sekarang), revise (merubah dan mengadopsi solusi yang ditawarkan jika perlu) dan retain (memakai solusi baru sebagai bagian dari kasus baru, kemudian kasus baru diupdate ke dalam basis kasus).

\section{REFERENSI}

[1] WHO, 2008. The Global Burden Of Diseas 2004 update, WHO Press Swittzerland, pp 28.

[2] Kemenkes RI, 2011, Profil Kesehatan Indonesia, Kemenkes RI, 2011, Jakarta, hal 41.
[3] Amiruddin, R., 2007. Current Issue Kematian Anak Karena Penyakit Diare.

[4] Hurlock, E. B, 1999. Psikologi Perkembangan: Suatu Pendekatan Sepanjang Ruang Kehidupan. Edisi 5. Jakarta: Erlangga. hal:33-35.

[5] Suwandi dan Usman. 1992. Mekanisme Kerja Antibiotik. Jakarta : PT. Kalbe Farma. hal:110.

[6] Arisman, 2004.Gizi dalam Daur Kehidupan. Buku Ajar Ilmu Gizi. Buku Kedokteran. Jakarta: EGC. hal:32-37.

[7] Pal, Sankar K. dan Shiu, Simon C.K. 2004. Foundations of Soft Case Based Reasoning. Indian Statstical Institute: Hong Kong Polytechnic University.

[8] Hendra, Tursina, Rudy D.N, 2017, Case Based Reasoning Penentuan Harga Rumah Dengan Menggunakan Metode Tversky, Jurnal Sistem dan Teknologi Informasi (JUSTIN), Vol.(1), No.(1), 2007.

[9] Mohammad, Husni, Rianto, Implementasi Knowledge Base pada Aplikasi Data Orang Hilang (Studi Kasus: Polres Tasikmalaya Kota), Jurnal Edukasi dan Penelitian Informatika (JEPIN), Vol.3,No(2).

[10] Pearce, E.C., 2009, Anatomi dan Fisiologi Untuk Paramedis, PT Grammedia Pustaka Utama, Jakarta, hal.86.

[11] Sloane, E., 2004, Anatomi Dan Fisiologi Untuk Pemula, Penerbit Buku Kedokteran EGC, Jakarta, hal 281.

[12] Aziz. 2006. Diare, Pembunuh Utama Balita. Graha Pustaka, Jakarta. hal 22-29.

[13] Ramaiah, S. 2000. All You Wanted to Know About Diare Jakarta :Gramedia. hal:32-39.

[14] Ngastiyah. 2003. Perawatan Anak Sakit, Jakarta: EGC. hal 21-22.

[15] Suharyono, 2008. Diare Akut, Klinik dan Laboratorik. Cetakan Kedua. Jakarta: Rineka Cipta. hal:23-28.

[16] Hapnes Toba dan Sylvia Tanadi. 2011. Pengembangan Case based reasoning pada Aplikasi Pemesanan Kain Berdasarkan Studi Kasus pada CV. Mitra KH Bandung. Jurnal Penelitian. Bandung : Fakultas Teknologi Informasi Universitas Kristen Maranatha.

[17] Aamodt, A \& Plaza, E, 1994, Case Based Reasoning: Foundation Issues Methodological Variations, and System Approaches, AI Communication Vol 7 Nr, 1 March 1994, pp 39-59.

[18] Sukamto, Rosa Ariani dan M. Shalahudin. 2013. Rekayasa Perangkat Lunak Terstruktur dan Berorientasi Objek. Bandung: Informatika.

[19] Fowler, Martin. 2005. UML Distilled 3th Ed., Panduan Singkat Bahasa Pemodelan Objek Standar. Yogyakarta: Andi.

[20] Luthfi, Emha Taufiq. 2010. Penerapan Case based reasoning Dalam Mendukung Penyelesaian Kasus. Yogyakarta. 